\title{
Sistem Operasional Koperasi Langit Biru Dalam Perspektif Hukum Positif dan Hukum Islam*
}

\author{
(OPERATIONAL SYSTEMS OF "KOPERASI LANGIT BIRU" \\ PERSPECTIVE POSITIVE LAW AND ISLAMIC LAW)
}

\author{
Gesha Romadona Aulia \\ Fakultas Syariah dan Hukum UIN Jakarta \\ Jl. Ir. H. Juanda No. 95 Ciputat Tangsel \\ E-mail: gesha@yahoo.co.id
}

\begin{abstract}
Koperasi Langit Biru as enterprises need capital in accordance with the scope and type of business. Koperasi Langit Biru's capital obtained from members who invest. The system used is a revenue sharing system, in which each member of the investment will earn a profit of Rp. 10.000, -/day/Kg of meat. The cooperative way of working using a binary system (network), the members of the above (upline) invites new members (downline) of at least 10 people to get a bonus of cooperative. The pattern of this cooperative operation was initially wowed investors, but when insolvent, causing incredible disappointment from various circles. Therefore, this study wants to analyze how Islam regards the law Cooperative of Langit Biru's management.
\end{abstract}

Keywords: Cooperative, Operations, Islamic Law

\begin{abstract}
Abstrak: Koperasi Langit Biru sebagai badan usaha memerlukan modal sesuai dengan lingkup dan jenis usahanya. Permodalan Koperasi Langit Biru didapat dari para anggota yang berinvestasi. Sistem yang dipakai adalah sistem bagi hasil, dimana setiap anggota yang berinvestasi akan mendapatkan profit sebesar Rp. 10.000,-/hari/Kg daging. Cara kerja Koperasi ini dengan menggunakan sistem binary (jaringan), yaitu anggota yang diatas (upline) mengajak anggota baru (downline) minimal 10 orang untuk mendapatkan bonus dari koperasi. Pola operasional koperasi ini pada mulanya memukau para investor, akan tetapi pada saat mengalami kepailitan, maka timbul kekecewaan yang luar biasa dari berbagai kalangan. Karenanya, penelitian ini ingin menganalisis bagaimana hukum Islam memandang pola manajemen Koperasi Langit Biru ini.
\end{abstract}

Kata Kunci: Koperasi, Operasional, Hukum Islam

* Diterima tanggal naskah diterima: 17 Maret 2013, direvisi: 23 April 2013, disetujui untuk terbit: 11 Mei 2013. 


\section{Pendahuluan}

Islam tidak melarang sama sekali umatnya untuk berlomba lomba dalam mencari kekayaan. Bahkan kaya dalam Islam di anjurkan, sebab dengan kekayaan bukan hanya membuka pintu kesenangan dan kesejahteraan. Jika ditelusuri lagi, umat Islam yang kaya bisa bermanfaat baik bagi dirinya atau pun orang-orang disekitarnya. Membayar zakat, infaq, bersedekah maupun pergi haji itu semua ibadah yang memerlukan kemampuan secara finansial. Karena kemiskinan hanya mendekatkan diri pada kekufuran. Namun dalam mencari harta terdapat aturan main, yakni tidak melanggar hal-hal yang diharamkan Allah SWT. Karena Islam pada dasarnya mengajak umatnya untuk menunjukkan prestasi dengan kompetensi yang sehat. Ibadah dalam lingkup yang luas meliputi segala aktivitas manusia yang positif dan tidak menyalahi ajaran Islam, selama hal itu diorientasikan (diniatkan) demi mencari keridhaan Allah swt. ${ }^{1}$

Begitupun halnya dengan mencari harta kekayaan dijalan Allah swt merupakan suatu ibadah. Berusaha untuk mencari kekayaan dapat di lakukan dengan berbagai cara yang baik, seperti berdagang misalnya. Rasulullah SAW adalah seorang pebisnis dan pedagang yang handal. Visi beliau dalam berdagang hanya satu, yaitu bahwa transaksi bisnis sama sekali tidak ditujukan untuk memupuk kekayaan pribadi, namun justru untuk membangun kehormatan dan kemuliaan bisnis dengan etika yang tinggi. Adapun hasil yang didapat harus di distribusikan kesebanyak mungkin umat. $^{2}$

Selain berdagang bisa juga sebagai pegawai, baik pegawai negeri maupun pegawai swasta. Asalkan ia mampu untuk melaksanakan kewajibannya sebagai pegawai dengan penuh tanggung jawab. Semakin maju sebuah peradaban daya kreativitas manusia turut berkembang. Begitupun halnya dalam mencari kekayaan, yang sebelumnya hanya berdagang atau menjadi seorang pegawai. Kini bagaimana sebagian hasil dari berdagang atau pun gaji yang diterima sebagai pegawai bisa lebih berkembang tidak hanya sekedar ditabung, hal ini dapat dilakukan dengan cara berinvestasi dan hal ini tidak dapat dilakukan secara individual melainkan sebagai anggota dari

\footnotetext{
${ }^{1}$ Arifin Hamid, Hukum Ekonomi Islam (Ekonomi Syariah) Di Indonesia Aplikasi dan Prospektifnya, cet. I, (Bogor: Ghalia Indonesia, 2007), h. 10.

2 "Cara berdagang rasulullah", artikel diakses pada 2 November 2012 dari http://cara- muhammad.com/perilaku/cara-berdagang-rasulullah-saw/
} 
suatu kelompok masyarakat. Bahwa jika semula dalam pemecahan kebutuhan hidupnya, manusia melakukannya secara individual, maka dalam perkembangannya manusia berusaha melakukannya secara bersamasama dan dalam perkembangan lebih lanjut, cara- cara yang digunakan oleh masyarakat untuk memecahkan permasalahan ekonomi yang mereka hadapi itu berbeda-beda, seiring dengan berkembangnya zaman. ${ }^{3}$

Terdapat persamaan antara menabung dengan berinvestasi, yakni keduanya memanfaatkan sebagian hasil yang didapat untuk memperoleh manfaat yang lebih besar. Namun pada umumnya tabungan dimanfaatkan untuk mengantisipasi kemungkinan keperluan uang mendadak, seperti sakit misalnya. Sedangkan investasi diharapkan untuk memperoleh keuntungan dimasa yang akan datang. Gitman pada dasarnya berpendapat bahwa investasi (jangka panjang) atau pengeluaran modal (capital expenditure) adalah komitmen untuk mengeluarkan sejumlah dana tertentu pada saat sekarang untuk memungkinkan perusahaan menerima manfaat di waktu yang akan datang, dua tahun atau lebih. ${ }^{4}$

Investasi dilihat dari wujud objek investasi dapat dibedakan kedalam (a) investasi riil, (real investment), dan (b) investasi financial (financial investment). Investasi riil adalah investasi yang dilakukan atas aktiva nyata, seperti pembelian mesin, rumah, tanah, mobil, emas dan berbagai aktiva nyata lainnya. Investasi finasial meliputi investasi atas surat-surat berharga (efek), valuta asing, deposito, meminjamkan uang secara komersil kepada pihak lain, dan sebagainya. ${ }^{5}$

Kini semakin banyak orang yang melakukan investasi. Banyaknya jenis investasi yang tersedia, hal ini menjadikan para investor harus jeli dalam memilih jenis investasi yang akan diikuti, yang sekiranya dianggap kompetetif dalam hasil return yang akan diterima oleh investor. Karena dalam berinvestasi pun memiliki resiko, baik itu kecil, moderat atau pun tinggi.

\footnotetext{
${ }^{3}$ Hendrojogi, Koperasi Azas-azas, Teori dan Praktek, cet. IV edisi 3, (Jakarta: PT. Raja Grafindo Persada, 2002), h. 2.

${ }^{4}$ Murdifin Haming, dan Salim Basalamah, Studi Kelayakan Investasi Proyek dan Bisnis, (Jakarta: Bumi Aksara, 2010), h. 6.

${ }^{5}$ Murdifin Haming, dan Salim Basalamah, Studi Kelayakan Investasi Proyek dan Bisnis, h. 370
} 
Investasi sekarang ini tidak hanya dalam bentuk saham, obligasi, rumah, tanah, mobil atau pun emas, ada pula investasi yang akhir - akhir ini sedang marak yakni, investasi daging yang dikelola oleh Koperasi Langit Biru yang sebelumnya bernama PT. Transindo Jaya Komara (PT. TJK). Investasi daging ini menjanjikan profit yang fantastis dan dalam waktu yang singkat dengan return yang cukup besar bahkan hingga ratusan persen pertahun yakni imbal hasilnya mencapai 258,97 persen dalam dua tahun atau 10 persen sebulan dari nilai penyertaan. ${ }^{6}$ Sehingga tidak sedikit yang tergiur untuk menjadi investor agar memperoleh kekayaan dengan waktu yang singkat dan cara yang cukup mudah.

Semenjak didirikan pada Januari 2011, Koperasi Langit Biru berhasil menghimpun 125.000 anggota dengan total dana investasi mencapai Rp 6 triliun.7 Pada awalnya Koperasi Langit Biru berjalan dengan lancar. Namun, sejak akhir 2011 silam, Koperasi Langit Biru mengalami kemacetan pencairan bonus terhadap para nasabah. Februari 2012 lalu, ribuan nasabah mulai resah karena manajemen Koperasi Langit Biru terus menunda-nunda pencairan bonus. Puncaknya, April 2012, para nasabah mendatangi kantor Koperasi Langit Biru di Cikasungka, Kecamatan Solear, Kabupaten Tangerang. Hingga akhirnya, pada awal Juni lalu, para nasabah menjarah produk sembako di gudang Koperasi Langit Biru.

Berangkat dari permasalahan ini, penulis tertarik membahas lebih jauh mengenai aturan koperasi baik secara hukum positif maupun dalam pandangan hukum Islam. Penulis mencoba mengangkat permasalahan ini dengan judul: "Sistem Operasional Koperasi Langit Biru Dalam Perspektif Hukum Positif Dan Hukum Islam."

\section{Koperasi Dalam Perspektif Hukum Positif}

Kata koperasi secara etimologi atau segi bahasa "cooperation" dari bahasa Inggris yang berarti bekerjasama. Akan tetapi tidak semua bentuk

${ }^{6}$ Adi Suhendi, "Bos Koperasi Langit Biru Bisa Dijerat Pasal Berlapis", artikel diakses pada 3 Januari 2013 dari http://www.tribunnews.com/2012/07/25/bos-koperasi-bumi-langitbisa-dijerat- pasal-berlapis

7 Sabrina Asril, "Polisi Telusuri Dugaan Pencurian Uang di Koperasi Langit Biru", artikel diakses pada $30 \quad$ Pebruari 2013 dari http://tekno.kompas.com/read/2012/06/06/20162383/Polisi.Telusuri.Dugaan.Pencucian.Uang.di. Koper asi.Langit.Biru 
usaha bersama disebut koperasi. Secara umum yang dimaksud dengan koperasi adalah "suatu badan usaha bersama yang bergerak dalam bidang perekonomian, beranggotakan mereka yang berekonomi lemah yang bergabung secara sukarela dan atas dasar persamaan hak, berkewajiban melakukan suatu usaha yang bertujuan memenuhi kebutuhan-kebutuhan para anggotanya". Koperasi merupakan suatu badan usaha bersama yang berjuang dalam bidang ekonomi dengan menempuh jalan yang tepat dan mantap dengan tujuan membebaskan diri para anggotanya dari kesulitankesulitan ekonomi yang umumnya diderita oleh mereka. ${ }^{8}$

R.M. Margono Djojohadikoesoemo dalam bukunya yang berjudul Sepuluh Tahun Koperasi: Penerangan tentang Koperasi oleh Pemerintah Tahun 1930-1940, menyatakan bahwa koperasi adalah perkumpulan manusia seorang-seorang yang dengan sukanya sendiri hendak bekerja sama untuk memajukan ekonominya. ${ }^{9}$

Definisi lain tentang koperasi dikemukakan oleh Paul Hubert Casselman dalam bukunya yang berjudul: "The Cooperative Movement and some of its Problems" mengatakan: "Cooperation is an economic system with social contract" (koperasi adalah suatu system ekonomi yang mengandung unsure social). ${ }^{10}$

Menurut kamus besar Bahasa Indonesia, pengertian Koperasi adalah "perkumpulan juga berusaha dilapangan ekonomi, tetapi tidak bermaksud mencari untung". ${ }^{11}$ Masyarakat Indonesia baru mulai mengenal bentuk koperasi pada awal abad ke-XIX. Seorang patih di Purwekerto bernama R. Aria Wiria Atmadja pada tahun 1896 mendirikan organisasi semacam koperasi simpan pinjam yaitu hulp and spaarbank (bank simpanan) untuk menolong priyayi (pegawai negeri) agar terhindar dari cengkraman lintah darat. Usaha ini, dibantu oleh asisten residen Purwekerto E. Sieburgh. Pada tahun 1898 inisiatif R. Aria Wiria Atmadja diperluas oleh

${ }^{8}$ G. Kartasapoetra, Koperasi Indonesia yang Berdasarkan Pancasila dan UUD 1945, cet. V, (Jakarta: Rineka Cipta, 2001), h. 1.

${ }_{9}$ Andjar Pachta W, dkk, Hukum Koperasi Indonesia Pemahaman, Regulasi, Pendirian dan Modal Usaha, (Jakarta: Kencana, 2007), h. 19.

${ }_{10}$ Muhammad Firdaus dan Agus Edhi Susanto, Perkoperasian Sejarah, teori dan Praktek, cet. I, (Jakarta: Ghalia Indonesia, 2002), h. 39.

${ }^{11}$ Wilfridus Josephus Sabarija Poerwadarminta, Kamus Umum Bahasa Indonesia, cet. IV, (Jakarta: P.N. Balai Pustaka, 1966), h. 466. 
De Wolf van Westerrode, pengganti E. Sieburgh. Bank itu tidak hanya membantu pegawai negeri saja, tetapi juga petani dan pedagang kecil. ${ }^{12}$

Secara ideologis, masalah utama yang dihadapi oleh bangsa Indonesia adalah bagaimana membangun system ekonomi yang sesuai dengan cita-cita tolong-menolong. Pertanyaan ideologis tersebut terjawab bahwa dasar perekonomian yang sesuai dengan cita-cita tolong-menolong ialah koperasi. Seluruh perekonomian rakyat harus berdasar koperasi. Koperasi mendahulukan keperluan bersama dan menomorduakan kepentingan individual. Oleh karena itu, koperasi harus memiliki fungsi mendidik masyarakat dalam hal mengurus keperluan bersama. ${ }^{13}$

Mohammad Hatta dalam pidatonya tanggal 12 Juli 1951 mengatakan sebagai berikut: “Apabila kita membuka Undang-Undang Dasar Tahun 1945 dan membaca serta menghayati isi Pasal 38, maka tampaklah di sana akan tercantum dua macam kewajiban atas tujuan yang satu. Tujuannya ialah menyelenggarakan kemakmuran rakyat dengan jalan menyusun perekonomian sebagai usaha bersama berdasar atas asas kekeluargaan. Perekonomian sebagai usaha bersama dengan berdasarkan kekeluargaan adalah koperasi, karena koperasi lah yang menyatakan kerja sama antara mereka yang berusaha sebagai suatu keluarga. Disini tak ada pertentangan antara majikan dan buruh, antara pemimpin dan pekerja. Segala yang bekerja adalah anggota koperasinya, sama-sama bertanggung jawab atas keselamatan koperasi itu.

Sebagaimana orang sekeluarga bertanggung jawab atas keselamatan rumah tangganya, demikian pula para anggota koperasi sama-sama bertanggung jawab atas koperasi mereka. Makmur koperasinya, makmurlah hidup mereka bersama, rusak koperasinya, rusaklah hidup mereka bersama." 14

Pengertian koperasi menurut Undang-Undang Koperasi juga memiliki perubahan. Undang-Undang Koperasi Nomor 14 Tahun 1956, Bab III pasal 3 mengatakan bahwa koperasi adalah organisasi ekonomi dan alat revolusi

12 Muhammad Firdaus dan Agus Edhi Susanto, Perkoperasian: Sejarah, Teori, dan Praktek, cet. II, (Bogor: Ghalia Indonesia, 2004), h.28.

${ }^{13}$ Mohammad Hatta, Beberapa Fasal Ekonomi, Djalan Ke Ekonomi dan Koperasi, (Jakarta: Perpustakaan Perguruan Kementrian P.P. dan K, 1954), h. 266.

${ }^{14}$ Andjar Pachta W, dkk, Hukum Koperasi Indonesia Pemahaman, Regulasi, Pendirian dan Modal Usaha, h. 19-20. 
yang berfungsi sebagai tempat persemaian insan masyarakat serta wahana menuju sosialisme Indonesia berdasarkan Pancasila. Menurut UndangUndang Nomor 12 Tahun 1967 Tentang Pokok- Pokok Perkoperasian pada Bab III Bagian I Pasal 3 dikatakan bahwa koperasi Indonesia adalah organisasi ekonomi rakyat yang berwatak sosial, beranggotakan orang-orangatau badanbadan hukum koperasi yang merupakan tata susunan ekonomi sebagai usaha-usaha bersama berdasar atas asas kekeluargaan. Untuk lebih menyesuaikan dengan perkembangan zaman, maka pada tanggal 21 Oktober 1992 dikeluarkan Undang-Undang baru, yaitu Undang- Undang Nomor 25 Tahun 1992 tentang Perkoperasian. Dalam Pasal 1 ayat (1) koperasi adalah badan usaha yang beranggotakan orang seorang atau badan hukum koperasi dengan melandaskan kegiatannya berdasarkan prinsip koperasi sekaligus sebagai gerakan ekonomi rakyat yang berdasarkan atas asas kekeluargaan. ${ }^{15}$

Koperasi Indonesia adalah organisasi ekonomi rakyat yang berwatak sosial beranggotakan orang-orang, badan-badan hukum koperasi yang merupakan tata susunan ekonomi sebagai usaha berdasar atas asas kekeluargaan. ${ }^{16}$

Dengan diberlakukannya Undang-Undang Nomor 25 Tahun 1992 tentang Perkoperasian maka terjadi perubahan yang cukup signifikan dalam pergerakan koperasi di Indonesia. Dimana pada undang-undang yang baru tidak disebutkan secara eksplisit adanya unsur sosial, walaupun secara implisit tersirat dalam prinsip-prinsip koperasi dan asas koperasi. ${ }^{17}$

\section{Koperasi Dalam Perspektif Hukum Islam}

Koperasi dalam fiqh Islam dikenal dengan Syirkah atau semakna dengan kata Al-Syirkah atau semakna dengan "al-Ikhtilat" yaitu suatu perserikatan/perkongsian. Adapun dari segi istilah, koperasi adalah akad antara orang-orang untuk berserikat modal dan keuntungan. ${ }^{18}$

15 Undang-Undang Perkoperasian 1992 (Undang-Undang No. 25 Th. 1992), cet. II. (Jakarta: Sinar Grafika, 1993), h. 2.

16 Ahmad Dimyanti, dkk. Islam dan Koperasi: Telaah Peran Serta Umat Islam dalam Pengembangan Koperasi, (Jakarta: Koperasi Jasa Informasi (KOPINFO), 1989), h. 12.

17 Subandi, Ekonomi Koperasi (Teori dan Praktik), cet. IV, (Bandung: Alfabeta, 2013), h. 15.

18 Junaedi B.SM., Islam dan Intreprenedrialisme: Suatu Studi Fiqh Ekonomi Bisnis Modern, (Jakarta: Kalam Mulia, 1993), h. 147. 
Syirkah dalam bahasa Arabnya berarti percampuran atau interaksi. Bisa juga artinya membagikan sesuatu antara dua orang atau lebih menurut hukum kebiasaan yang ada. Beberapa pengertian al-syirkah secara terminologis yang disampaikan oleh fuqaha Mazhab empat adalah sebagai berikut: "Menurut fuqaha Malikiyah, al-syirkah adalah kebolehan (atau izin) bertasharruf bagi masing-masing pihak yang berserikat. Maksudnya masingmasing pihak yang saling memberikan izin dan pihak lain dalam mentasharrufkan harta (objek) perserikatan. Menurut fuqaha Hanabilah, alsyirkah adalah persekutuan dalam hal hak dan tasharruf. Menurut fuqaha Syafi"ciyah, al-syirkah adalah berlakunya hak atas sesuatu bagi dua pihak atau lebih dengan tujuan persekutuan. Sedang menurut fuqaha hanafiyah, alsyirkah adalah akad antara pihak-pihak yang berserikat dalam hal modal dan keuntungan". ${ }^{19}$

Sebagian ulama menganggap koperasi (Syirkah Ta'uwuniyah) sebagai akad mudharabah, yakni suatu perjanjian kerjasama antara dua orang atau lebih, disatu pihak menyediakan modal usaha, sedangkan pihak lain melakukan usaha atas dasar profit sharing (membagi keuntungan) menurut perjanjian, dan di antara syarat sah mudharabah itu adalah menetapkan keuntungan setiap tahun dengan presentase tetap, misal 1\% setahun kepada salah satu pihak dari mudharabah tersebut. Karena itu, apabila koperasi itu tidak menetapkan dengan keuntungan tersebut diatas (menetapkan presentase keuntungan tertentu kepada salah satu pihak mudharabah), maka akad mudharabah itu tidak sah atau batal, dan seluruh keuntungan usaha jatuh kepada pemilik modal, sedangkan pelaksana usaha mendapat upah yang sepadan atau pantas. Mahmud Syaltut tidak setuju dengan pendapat tersebut, sebab Syirkah Ta'uwuniyah tidak mengandung unsur mudharabah yang dirumuskan oleh fukaha. Sebab Syirkah Ta'uwuniyah, modal usahanya adalah dari sejumlah anggota pemegang saham, dan usaha koperasi itu dikelola oleh pengurus dan karyawan yang dibayar oleh koperasi menurut kedudukannya masing-masing. Kalau pemegang saham turut mengelola usaha koperasi itu, maka ia berhak mendapat gaji sesuai dengan sistem penggajian yang berlaku. ${ }^{20}$

19 Moch. Thohir „Aruf, Kemitraan dan Pembagian Profit Menurut Hukum Islam, (Jakarta: Prestasi Pustaka, 2009), h. 19-20.

${ }^{20}$ M. Ali Hasan, Berbagai Macam Transaksi dalam Islam (Fiqih Muamalat), h. 162-165. 


\section{Sejarah Berdirinya Koperasi Langit Biru}

Ustad Jaya Komara ialah pendiri sekaligus Direktur Utama Koperasi "Serba Usaha" Langit Biru yang terletak di Bukit Cikasungka Blok ADF 13 No. 2-5 Desa Cikasungka Kecamatan Solear Kabupaten Tangerang Banten, 15730. Awalnya Jaya Komara pindah ke Bukit Cikasungka bersama istri dan 9 anaknya pada tahun 2003, disana ia dan keluarganya menempati rumah kosong. Sebagai warga pendatang, Jaya Komara berperilaku baik di mata warga sekitar dan terkenal ulet dengan usaha yang dirintisnya mulai dari tanam belut, tanam lele dan minyak godog untuk pijat. Hampir seluruh warga Bukit Cikasungka, pernah diurut oleh Jaya Komara. Jasa pengobatan Jaya Komara ini sudah tersohor di lingkungan warga sekitar. Tidak hanya warga sekitar, tapi penduduk luar kampung juga banyak yang menggunakan keahliannya dalam berobat itu. Selain itu Jaya Komara dikenal sebagai penceramah di masjid-masjid sekitar, dan mengisi ceramah di kawasan kebon jeruk, Jakarta. Kegiatan ceramah dan tabligh akbar ini ia lakoni sejak tahun 2003 atau mulai awal ia menempati rumah di bukit Cikasungka. Hingga akhirnya ia mendapat panggilan Ustad Jaya Komara. Jaya Komara dikenal warga sebagai pria yang ulet. Segala macam pekerjaan dan usaha pernah ia tekuni. Perlahan-lahan, Jaya Komara bangkit dari keterpurukan. Hingga akhirnya sekitar tahun 2005, Jaya Komara berjualan daging ke warga sekitar. Daging yang ia jual itu, ia dapatkan dari suplier. Dalam menjalankan bisnisnya, ia menawarkan sistem kredit daging. Setiap warga yang mengambil daging darinya, tidak pernah dipaksa untuk membayar sesuai tarifnya. Pada saat itu harga daging sebesar Rp. 60.000,- perkilogram, ia tidak pernah mematok kredit yang harus dibayar setiap hari. Dengan keikhlasannya dalam berjualan, ia tidak pernah mengingat-ingat berapa catatan utang warga yang mengambil daging darinya. Meski demikian, warga sekitar punya kesadaran sendiri dalam membayar utangnya ke Jaya Komara. Atas landasan itu, warga sekitar mulai banyak yang tertarik. Lamalama, pesananan daging dari Jaya Komara semakin banyak peminatnya. Hingga akhirnya, ia menawarkan daging untuk paket lebaran. Disitulah puncak kejayaan Jaya Komara. Hingga pada tahun 2010, bisnisnya dalam daging itu ia kembangkan. Ia pun kemudian mendirikan PT. Transindo Jaya Komara (TJK) yang bergerak di bidang investasi daging. Sistem yang dipakai di PT. Transindo Jaya Komara adalah sistem bagi hasil. Dimana, setiap investor yang menginvestasikan uangnya di PT. Transindo Jaya Komara akan mendapatkan bonus sekitar 10 persen. Ibu Genta adalah investor 
pertamanya kala itu. Ia mengambil paket besar (100 kg daging) dengan nilai investasi Rp 8,5 juta. Ibu Genta mendapatkan bonus Rp 1,7 perbulannya untuk investasinya itu.

Sebagai investor pertama, Ibu Genta juga kecipratan untung. Ia mampu mengumpulkan ratusan hingga ribuan downline. Nilai investasi yang dikumpulkan downline pun mencapai Rp 2 miliar. Atas usahanya itu, perekonomian Jaya Komara meningkat. Dari awalnya yang hanya menempati rumah kecil, Jaya Komara kini mampu membeli rumah dua lantai dengan ukuran besar. Bahkan, ia mampu membeli tanah perkebunan Bukit Cikasungka seluas sekitar 1 hektar. ${ }^{21}$

Seiring dengan semakin pesatnya usaha Komara ini, perusahaan pun berubah nama menjadi Koperasi Langit Biru. Koperasi Langit Biru sendiri berdiri atas dasar Akta Notaris Winda Wirata No.24 Tanggal 9 April 2011. Izin koperasi dikeluarkan oleh Dinas Koperasi dan UMKM Propinsi Banten, tanggal 20 Juli 2011 No. 81/BH/XI/KUMKM/VII/2011. Koperasi Langit Biru terdaftar sebagai Koperasi Simpan Pinjam/Unit Simpan Pinjam sebagaimana yang tertera pada Surat Keterangan Terdaftar dari Kementerian Keuangan Republik Indonesia, Direktorat Jendral Pajak.

Setiap pendaftaran harus menggunakan sponsor, tidak dapat mendaftarkan diri sebagai anggota Koperasi Langit Biru secara personal. Koperasi Langit Biru menggunakan sistem binary (jaringan), yaitu anggota yang diatas (upline) mengajak anggota baru (downline) minimal 10 orang. Bila calon anggota berhalangan datang sendiri pendaftaran bisa dititipkan kepada sponsor.

\section{Sistem Operasional Koperasi Langit Biru}

Setiap perkumpulan atau organisasi dalam melakukan kegiatan untuk mencapai tujuannya memerlukan sejumlah modal. Sebagai badan usaha, koperasi memerlukan modal sesuai dengan lingkup dan jenis usahanya. Begitupun halnya dengan Koperasi Langit Biru memerlukan modal untuk menjalankan kegiatan koperasi. Permodalan Koperasi Langit Biru didapat

21 E Mei Amelia R, “Jaya Komara Langit Biru, Dari Tukang Urut Hingga Jadi Triliuner", artikel diakses pada 28 Januari 2014 dari http://finance.detik.com/read/2012/06/11/080037/1937628/10/9/jaya-komara-langit-biru-daritukang- urut-hingga-jadi-triliuner 
dari para anggota koperasi yang berinvestasi pada Koperasi Langit Biru. Sistem yang dipakai di Koperasi Langit Biru adalah sistem bagi hasil. Di mana, setiap anggota yang berinvestasi di Koperasi Langit Biru akan mendapatkan profit sebesar Rp. 10.000,-/ hari/ Kg daging. Cara kerja Koperasi Langit Biru yakni menggunakan sistem binary (jaringan), yaitu anggota yang di atas (upline) mengajak anggota baru (downline) minimal 10 orang untuk mendapatkan bonus dari koperasi dengan menyertakan data data anggota baru (downline) dan nilai investasi yang dipilih. Bagi anggota yang ingin berinvestasi, Koperasi Langit Biru memiliki dua mekanisme investasi, yakni mekanisme investasi daging dengan paket kecil dan mekanisme investasi daging dengan paket besar. Yang dimaksud dengan investasi paket kecil adalah paket mulai dari $5 \mathrm{~kg}$ daging sampai dengan 95 $\mathrm{kg}$ daging, sedangkan investasi paket besar adalah paket $100 \mathrm{~kg}$ daging. Para anggota baru (downline) dapat memilih nilai invetasi yang diinginkan. Setiap anggota, baik yang berinvestasi paket kecil maupun paket besar mendapatkan hasil dari nilai investasi berupa uang, bonus produk sponsor, dan bonus Ibadah Keagamaan. Bonus yang diterima setiap bulan oleh anggota sesuai dengan nilai investasi yang di tanamkan oleh anggota. Untuk bonus produk telah ditetapkan oleh Koperasi Langit Biru. Bonus produk untuk bonus individu di atas Rp. 75.000,- sampai dengan Rp.450.000,mendapatkan bonus produk senilai Rp. 30.000,- berupa kecapa 1 botol, saos pedas/saos tomat 1 botol, gula pasir 0,5 kilogram dan bawang putih 0,5 kilogram. Bonus produk untuk bonus individu di atas Rp. 525.000,sampai dengan Rp. 975.000,- mendapatkan bonus produk senilai Rp. 250.000,- berupa bawang putih, daging, gula merah, gula pasir, beras organik masing-masing 1 kilogram, kecap, saos pedas, saos tomat masing masing 1 botol, telur asin brebes 2 butir, minyak goreng 5 liter dan safwa 1 dus, berdasarkan penuturan salah satu nasabah Koperasi Langit Biru safwa adalah air mineral dalam kemasan yang merupakan salah satu unit usaha yang dikembangkan oleh Koperasi Langit Biru. Bonus produk untuk bonus individu di atas Rp.1.000.000,- mendapatkan bonus produk senilai Rp. 350.000,- berupa bawang putih, daging, gula merah, gula pasir, beras organik masing-masing 1 kilogram, kecap, saos pedas, saos tomat masing-masing 1 botol, minyak goreng 5 liter, telur asin brebes 6 butir, safwa 1 dus, beras organik 2 kilogram, sreg 1 paket dan metalik 1 buah. Untuk pengambilan hasil dari nilai investasi berupa uang dan bonus produk, setiap investor diwajibkan membawa kwitansi sebagai tanda bukti bahwa orang tersebut merupakan anggota dari Koperasi Langit Biru. Apabila bukti 
kwitansi tersebut hilang maka uang dan bonus produk tidak dapat di ambil atau di anggap hangus.

\section{Sistem Operasional Koperasi Langit Biru Menurut Hukum Positif dan Hukum Islam}

Dalam pasal 41 UU RI No.25/1992 dikatakan bahwa: (1) Modal Koperasi terdiri dari modal sendiri dan modal pinjaman. (2) Modal sendiri dapat berasal dari: a. Simpanan pokok; b. Simpanan wajib; c. Dan cadangan; d. Hibah. (3) Modal pinjaman dapat berasal dari: a. Anggota; b. Koperasi lainnya dan/atau Anggotanya; c. bank dan lembaga keuangan lainnya; d. penerbitan obligasi dan surat hutang lainnya; e. sumber lain yang sah. ${ }^{22}$

Pada Koperasi Langit Biru permodalan didapat dari para anggota koperasi yang berinvestasi pada Koperasi Langit Biru. Berdasarkan hasil wawancara dengan salah satu anggota Koperasi Langit Biru untuk menjadi anggota Koperasi Langit Biru tidak ada simpanan pokok ataupun simpanan wajib yang harus dibayarkan, yang ada hanya membayar sesuai dengan nilai investasi yang dipilih oleh calon anggota koperasi. Menurut pasal 45 UU RI No.25/1992 dikatakan bahwa: (1) Sisa Hasil Usaha merupakan pendapatan Koperasi yang diperoleh dalam satu tahun dikurangi biaya, penyusutan, dan kewajiban lainnya termasuk pajak dalam tahun buku yang bersangkutan. (2) Sisa Hasil Usaha setelah dikurangi dana cadangan, dibagikan kepada anggota sebanding dengan jasa usaha yang dilakukan oleh, masing- masing anggota dengan Koperasi, serta digunakan untuk keperluan pendidikan perkoperasian dan keperluan lain dari Koperasi, sesuai dengan keputusan Rapat Anggota. (3) Besarnya pemupukan dana cadangan ditetapkan dalam Rapat Anggota. ${ }^{23}$

Sistem yang dipakai oleh Koperasi Langit Biru adalah sistem bagi hasil. Setiap anggota yang menginvestasikan uangnya di Koperasi Langit Biru akan mendapatkan profit sebesar Rp. 10.000,-/ hari/ Kg daging. Koperasi Langit Biru telah menentukan sendiri sisa hasil usaha yang akan didapat oleh para anggota setiap bulannya berdasarkan nilai investasi anggotanya. Dengan mengacu pasal 45 UU RI No.25/1992 diatas maka besarnya Sisa Hasil Usaha diberikan dalam kurun waktu satu tahun dan yang akan diterima oleh

\footnotetext{
22 Undang-Undang Perkoperasian 1992 (Undang-Undang No. 25 Th. 1992), h. 14

${ }^{23}$ Undang-Undang Perkoperasian 1992 (Undang-Undang No. 25 Th. 1992), h. 15-16
} 
setiap anggota akan berbeda, tidak hanya melihat dari besar kecilnya partisipasi modal atau dalam Koperasi Langit Biru besar kecilnya nilai investasi, namun juga dilihat dari jasa usaha anggota, yakni peran aktif anggota dalam mengelola dan mengembangkan Koperasi Langit Biru. Begitupun dengan pemberian bonus kepada setiap anggota Koperasi Langit Biru, semua telah ditetapkan diawal. Kenyataannya dalam setiap bentuk usaha yang dilakukan baik oleh perorangan maupun kelompok memiliki resiko berupa kerugian yang akan dihadapi. Dari adanya kemungkinan resiko tersebut, sisa hasil usaha dan pemberian bonus tidak dapat ditetapkan diawal dan berlaku flat setiap bulannya. Koperasi Langit Biru mengelola dana anggotanya dengan cara menanamkan modal ke beberapa penyuplai daging. Dari modal yang ditanamkan oleh Koperasi Langit Biru ke para penyuplai daging tersebut, Koperasi Langit Biru mendapatkan keuntungan yang mana sebagian dari keuntungan tersebut Koperasi Langit Biru berikan kepada para anggota Koperasi Langit Biru selaku investor. Bagaimana bisa kita menetapkan keuntungan untuk bulanbulan berikutnya berlaku tetap, sedangkan harga daging di pasaran selalu fluktuatif atau berubah-ubah naik turun.

Perkembangan harga rata-rata daging sapi di tingkat nasional selama tahun 2011 hingga 2013 cenderung terus mengalami peningkatan dengan rata-rata masing-masing sebesar $0,42 \%, 1,60 \%$, dan 0,78\%. Pada bulan Januari 2011, harga daging sapi sebesar Rp. 68.124,-/kg dan meningkat menjadi Rp. 67.615,-/kg pada bulan Desember. Pada tahun 2012, harga daging sapi bergerak dari Rp. $71.890,-/ \mathrm{kg}$ menjadi Rp. 85.512,-/kg, dan pada tahun 2013 bergerak dari Rp. 86.625,-/kg menjadi Rp. 94.210,-/kg. Pada bulan Januari dan Pebruari 2014, harga daging sapi kembali mengalami kenaikan sebesar $0,67 \% .^{24}$

Dalam Islam bagi hasil (mudharabah) berasal dari kata dharb, yang artinya memukul atau berjalan. Pengertian berjalan atau memukul ini lebih tepatnya adalah proses seseorang memukul kakinya dalam menjalankan usaha. Lebih jauh kata dharb di sini di maksud usaha atau bekerja. Mudharabah sering dikatakan qiradh, karena mempunyai makna yang sama. Kata qiradh berasal dari kata qaradha, yaitu memotong, karena dalam kasus ini yang punya harta memotong sebagian hartanya untuk

24 "Buletin Analisis Perkembangan Harga: Maret 2014", Di akses pada tanggal 25 Agustus 2014 dari http://pusdatin.setjen.pertanian.go.id 
diperdagangkan (diproduktifkan dalam suatu usaha) dan mendapatkan potongan dari keuntungannya, berbagi hasil dengan yang mengusahakan hartanya itu. Pengertian mudharabah menurut syara' (menurut ahli fiqh) sebagai berikut: "pemilik harta atau modal menyerahkan hartanya kepada pekerja untuk diusahakan (dijadikan modal usaha) dan keuntungannya menjadi milik bersama dan dibagi menurut kesepakatan bersama." ${ }^{25}$

Mudharabah merupakan akad/persetujuan salah satu pihak untuk memberikan hartanya untuk dikelola oleh pihak yang dipercayainya. Dari hal tersebut, ada beberapa komponen penting dalam mudharabah. Masing-masing komponen penting itu adalah pihak yang memberikan modal saja di sebut shahib al-mal, pihak yang mengelola modal (mudharib), dan di antara keduanya ada kepercayaan yang membuat akad ini terlaksana. Unsur kepercayaan inilah yang membuat shahib al-mal tidak diperkenankan mensyaratkan kepada mudharib sesuatu yang berharga sebagai jaminan. Sehingga para ulama fiqih bersepakat bahwa persyaratan jaminan pada akad menyebabkan akad tersebut batal. ${ }^{26}$

Para ulama fiqih menetapkan bahwa akad mudharabah apabila telah memenuhi rukun dan syaratnya maka hukumnya adalah boleh. Rukun dan syarat mudharabah, yakni :

Pertama, adanya dua pelaku atau lebih, yaitu investor (pemilik modal) dan pengelola (mudharib). Kedua belah pihak yang melakukan akad disyaratkan mampu melakukan tasharruf atau cakap hukum, maka dibatalkan akad anak-anak yang masih kecil, orang gila, dan orang-orang yang berada di bawah pengampuan.

\section{Syarat-syarat Modal atau harta pokok (mal)}

Syarat Modal dan Harta pokok adalah sebagai berikut:

Pertama; Berbentuk uang. Mayoritas ulama berpendapat bahwa modal harus berupa uang dan tidak boleh barang. Mudharabah dengan barang dapat menimbulkan kesamaran, karena barang pada umumnya bersifat fluktuatif. Apabila barang itu bersifat tidak fluktuatif seperti berbentuk emas atau perak batangan (tabar), para ulama berbeda pendapat. Imam malik dalam hal

\footnotetext{
${ }^{25}$ Nasroen Haroen, Fiqih Muamalah, (Jakarta: Gaya Media Pratama, 2000), h. 176.

26 Dewan Redaksi Ensiklopedia Hukum Islam, Ensiklopedia Hukum Islam, Jilid 4, (Jakarta: PT. Ichtiar Baru Van Hoeve, 1994), h. 1197.
} 
ini tidak tegas melarang atau membolehkan. Namun para ulama mazhab Hanafi membolehkannya dan nilai barang yang dijadikan setoran modal harus disepakati pada saat akad oleh mudharib dan shahibul mal.

Kedua; Jelas jumlah dan jenisnya. Jumlah modal harus diketahui dengan jelas agar dapat dibedakan antara modal yang diperdagangkan dengan laba atau keuntungan dari perdagangan tersebut yang akan dibagikan kepada dua belah pihak sesuai dengan perjanjian yang telah disepakati.

Ketiga; Tunai. Hutang tidak dapat dijadikan modal mudharabah. Tanpa adanya setoran modal, berarti shahibul mal tidak memberikan kontribusi apapun padahal mudharib telah bekerja. Para ulama syafiei dan Maliki melarang hal itu karena merusak sahnya akad. Selain itu hal ini bisa membuka pintu perbuatan riba, yaitu memberi tangguh kepada si berhutang yang belum mampu membayar hutang dengan kompensasi si berpiutang mendapatkan imbalan tertentu. Dalam hal ini para ulama fikih tidak berbeda pendapat.

Keempat; Modal diserahkan sepenuhnya kepada pengelola secara langsung. Apabila tidak diserahkan kepada mudharib secara langsung dan tidak diserahkan sepenuhnya (berangsur-angsur) dikhawatirkan akan terjadi kerusakan pada modal, yaitu penundaan yang dapat mengganggu waktu mulai bekerja dan akibat yang lebih jauh mengurangi kerjanya secara maksimal. Apabila modal itu tetap dipegang sebagiannya oleh pemilik modal, dalam artian tidak diserahkan sepenuhnya, maka menurut ulama Hanafiyah, Malikiyah, dan Syafieiyah, akad mudharabah tidak sah. Sedangkan ulama Hanabilah menyatakan boleh saja sebagian modal itu berada di tangan pemilik modal, asal tidak mengganggu kelancaran usahanya. ${ }^{27}$

Dalam akad mudharabah proporsi keuntungan harus jelas. Keuntungan yang akan menjadi milik pengelola dan pemilik modal harus jelas persentasenya, seperti $60 \%: 40 \%, 50 \%: 50 \%$ dan sebagainya menurut kesepakatan bersama.

1. Keuntungan harus dibagi untuk kedua belah pihak, yaitu investor (pemilik modal) dan pengelola (mudharib).

${ }^{27}$ Dimyauddin Djuwaini, Pengantar Fiqh Mu'amalah, (Yogyakarta: Pustaka Pelajar, 2010), h. 178. 
2. Break Even Point (BEP) harus jelas, karena BEP menggunakan sistem revenue sharing dengan profit sharing berbeda. Revenue sharing adalah pembagian keuntungan yang dilakukan sebelum dipotong biaya operasional, sehingga bagi hasil dihitung dari keuntungan kotor/ pendapatan. Sedangkan profit sharing adalah pembagian keuntungan dilakukan setelah dipotong biaya operasional, sehingga bagi hasil dihitung dari keuntungan bersih.

3. Ijab Qobul. Melafazkan ijab dari pemilik modal, misalnya aku serahkan uang ini kepadamu untuk dagang jika ada keuntungan akan dibagi dua dan kabul dari pengelola. ${ }^{28}$

Namun pada kenyataannya Koperasi Langit Biru tidak menentukan keuntungan dengan persentase yang jelas melainkan dengan nilai rupiah yang telah ditentukan besaran nominalnya.

Imam Fakhruddin ar Razzy (1210M) mengatakan larangan riba dengan alasan. Pertama, karena riba berarti mengambil harta si peminjam secara tidak adil. Pemilik uang biasanya berdalih ia berhak atas keuntungan bisnis yang dilakukan si peminjam. Namun ia tampaknya lupa bila ia tidak meminjamkannya, uangnya tidak bertambah, ia pun berdalih kesempatan berbisnis hilang karena meminjamkan uangnya, karenanya ia berhak atas riba. Inipun keliru karena belum tentu bisnisnya menghasilkan untung dan pasti ia harus menanggung resiko. Kedua, dengan riba orang akan malas bekerja dan berbisnis karena dapat duduk- duduk tenang sambil menunggu uangnya berbunga. Imam ar-Razzy mengatakan bahwa tanpa adanya bekerja dan berbisnis, kegiatan produksi perdagangan akan lesu. Ketiga, riba akan merendahkan martabat manusia karena untuk memenuhi hasrat dunianya seseorang tidak segan-segan meminjam dengan bunga tinggi walau akhirnya dikejar-kejar penagih hutang. Keempat, riba akan membuat yang kaya bertambah kaya dan yang miskin bertambah miskin. Kelima. Riba jelas dilarang dalam Alquran dan al-Hadits. ${ }^{29}$

Koperasi Langit Biru memiliki tujuan yang sangat mulia, yaitu dengan dibentuknya koperasi ini diharapkan masyarakat khususnya umat Islam dapat lebih sejahtera. Namun pada kenyataannya koperasi ini belum sesuai dengan Hukum Islam. Mekanisme pemberian bonus yang diberikan

\footnotetext{
${ }^{28}$ Muhammad, Lembaga Keuangan Umat Kontemporer, (Yogyakarta: UII Press, 2000), h. 47

${ }^{29}$ Ibn Qayyim Al-Jauziyah, Buah Ilmu, cet. I, (Jakarta: Pustaka Azzam, 1999), h. 31.
} 
oleh Koperasi Langit Biru kepada para anggota setiap bulannya berlaku tetap atau flat. Padahal setiap bentuk usaha yang dilakukan terdapat resiko yang akan dihadapi, dengan itu Koperasi Langit Biru memberikan jaminan kepastian untung, dimana hal ini merupakan riba.

\section{Penutup}

Koperasi Langit Biru menggunakan sistem bagi hasil yang telah ditetapkan sendiri oleh koperasi dan berlaku sama pada setiap bulannya. Sedangkan menurut Undang-Undang Nomor 12 Tahun 1992 Tentang Perkoperasian, sisa hasil usaha diberikan dalam kurun waktu satu tahun setelah dikurangi biaya, penyusutan, dan kewajiban lainnya termasuk pajak dalam tahun buku yang bersangkutan. Maka berdasarkan penelitian tersebut diatas, dapat ditarik kesimpulan bahwa sistem operasional yang diterapkan oleh Koperasi Langit Biru belum sesuai Hukum Positif karena di dalam prakteknya masih bertentangan.

Koperasi Langit Biru tidak menggunakan persentase tetap, melainkan dengan rupiah sebesar Rp. 10.000,-/ hari/ Kg daging. Harga dagingnya bersifat flat dan berlaku sama di setiap bulannya, bagaimana bisa kita menetapkan keuntungan untuk bulan-bulan berikutnya flat dan selalu sama antara harga daging dan keuntungan yang didapat, sedangkan harga daging di pasaran selalu fluktuatif atau berubah-ubah naik turun. Mekanisme pemberian bonus yang diberikan oleh Koperasi Langit Biru kepada anggotanya pun sama setiap bulannya dan berlaku tetap, dengan itu Koperasi Langit Biru memberikan jaminan kepastian untung. Padahal sebagaimana pada umumnya dapat kita ketahui bahwa dalam setiap bentuk kegiatan usaha tidak dapat diketahui apakah usaha yang akan kita jalankan akan berjalan lancar atau tidak. Karena dalam setiap transaksi bisnis terdapat resiko. Maka berdasarkan penelitian tersebut diatas, dapat ditarik kesimpulan bahwa sistem operasional yang diterapkan oleh Koperasi Langit Biru belum sesuai Hukum Islam karena di dalam prakteknya masih terdapat unsur riba.

\section{Pustaka Acuan}

Al-Qur"an Karim, Terjemahan Departemen Agama Republik Indonesia. Afzalurrahman, Muhammad Sebagai Seorang 
Pedagang, Penerjemah. Dewi Nurjulianti, cet. II. Jakarta, Intermasa, 1997.

Al-Jauziyah, Ibn Qayyim, Buah Ilmu, cet. I. Jakarta, Pustaka Azzam, 1999.

Anoraga, Pandji, Manajemen Koperasi, Teori dan Praktek, cet. I. Jakarta, PT. Dunia Pustaka Jaya, 1995.

Antonio, Muhammad Syafi'i, Bank Sayri'ah Suatu Pengenalan Umum, Jakarta, Tazkia Institute, 1999.

Antonio, Muhammad Syafi'i, Bank syariah: dari Teori Ke Praktik, Jakarta, PT. Gema Insani Press, 2001.

Aruf, Moch. Thohir, Kemitraan dan Pembagian Profit Menurut Hukum Islam, akarta, Prestasi Pustaka, 2009.

Ash-Shan"ani, Muhammad bin Isma"il al-Amir al-Yamani, Subulus Salam, Juz 3. Beirut, Daar al-Kutub al-Ilmiyah, 1998.

Departemen Kehakiman RI, Pokok-Pokok Undang-Undang Dasar Tahun 1945, cet.XIII. Jakarta, Balai Pustaka, 1991.

Dewan Redaksi Ensiklopedia Hukum Islam, Ensiklopedia Hukum Islam, Jilid 4.

Jakarta, PT. Ichtiar Baru Van Hoeve, 1994.

Dimyati, Ahmad, dkk. Islam dan Koperasi : Telaah Peran Serta Umat Islam dalam

Pengembangan Koperasi, Jakarta Koperasi Jasa Informasi (KOPINFO), 1989.

Djazuli, Ahmad, Kaidah-Kaidah Fikih, cet. III. Jakarta, Kencana, 2010.

Djuwaini, Dimyauddin, Pengantar Fiqh Mu'amalah, Yogyakarta, Pustaka Pelajar, 2010.

Dumadi, Sagimun Mulus, Koperasi Soko Guru Ekonomi Nasional Indonesia, Jakarta, Haji Masagung, 1989.

Firdaus, Muhammad dan Agus Edhi Susanto, Perkoperasian: Sejarah, Teori, dan Praktek, cet. I. Bogor, Ghalia Indonesia, 2002.

Firdaus, Muhammad dan Agus Edhi Susanto, Perkoperasian: Sejarah, Teori, dan Praktek, cet. II. Bogor, Ghalia Indonesia, 2004. 
Hamid, Arifin, Hukum Ekonomi Islam (Ekonomi Syariah) Di Indonesia Aplikasi dan Prospektifnya, cet. I. Bogor, Ghalia Indonesia, 2007.

Haming, Murdifin, dan Salim Basalamah, Studi Kelayakan Investasi Proyek dan Bisnis, Jakarta, Bumi Aksara, 2010.

Haroen, Nasrun, Fiqh Mu'amalah, cet. I. Jakarta, Gaya Media Pratama, 2002. Haroen, Nasrun, Fiqih Muamalah, Jakarta, Gaya Media Pratama, 2000

Hasan, M. Ali, Berbagai Macam Transaksi dalam Islam (Fiqih Muamalat), Jakarta, PT. Raja Grafindo Persada, 2004.

Hassan, Asnawi, Koperasi dalam Pandangan Islam, INFOKOP, No. 1, Desember, 1984.

Hatta, Mohammad, Beberapa Fasal Ekonomi, Djalan Ke Ekonomi dan Koperasi, Jakarta, Perpustakaan Perguruan Kementrian P.P. dan K, 1954.

Hendrojogi, Koperasi Azas-azas, Teori dan Praktek, cet. IV. Jakarta, PT Raja Grafindo Persada, 2002.

Irawan, Prasetya, Logika dan Prosedur Penelitian, Pengantar Teori dan Panduan Praktis Penelitian Sosial bagi Mahasiswa dan Penelitian Pemula, Jakarta, STIA-LAN Press, 2004.

Kartasapoetra, G., Koperasi Indonesia yang Berdasarkan Pancasila dan UUD 1945, cet. V. Jakarta, Rineka Cipta, 2001.

Kusuma, Hadi, Hukum Koperasi Indonesia, Jakarta Raja Grafindo Persada, 2002. Laporan Penelitian, Koperasi Pondok Pesantren, Jakarta, Balitbang Depkop, 1986.

Miles, Matthew B. dan A. Michael Huberman, Analisa Data Kualitatif : buku tentang Sumber Metode-Metode Baru, Jakarta UI Press, 1992.

Moleong, Lexy J, Metode Penelitian Kualitatif, Bandung, Remaja Rosda karya, 2000. Muhammad, Lembaga Keuangan Umat Kontemporer, Yogyakarta, UII Press, 2000.

Munawwir, Ahmad Warson, Kamus AlMunawwi, cet. XIV. Surabaya, Pustaka Progressif, 1997. 
Pachta W, Andjar, Myra Rosana Bachtiar dan Nadia Maulisa Benemay, Hukum Koperasi Indonesia Pemahaman, Regulasi, Pendirian dan Modal Usaha, Jakarta, Kencana, 2007.

Poerwadarminta, Wilfridus Josephus Sabarija, Kamus Umum Bahasa Indonesia, Jakarta, P.H. Balai Pustaka, 1976.

Qudamah, Abdullah Ibn Ahmad Ibn Mughni Wa Syarh Kabir, vol. V. Beirut, Darul-Fikr, 1979, h. 109.

Shaleh, Rosyad, Management Dakwah Islam, Jakarta, Bulan Bintang, 1977.

Subandi, Ekonomi Koperasi (Teori dan Praktik), cet. IV. Bandung, Alfabeta, 2013.

SM, Junaedi B, Islam dan Intrepreneurialisme: Suatu Studi Fiqh Ekonomi Bisnis Modern, Jakarta, Kalam Mulia, 1993.

Undang-Undang Perkoperasian 1992 (UU NO. 25 TH. 19929, cet. II. Jakarta, Sinar Grafika, 1993. 